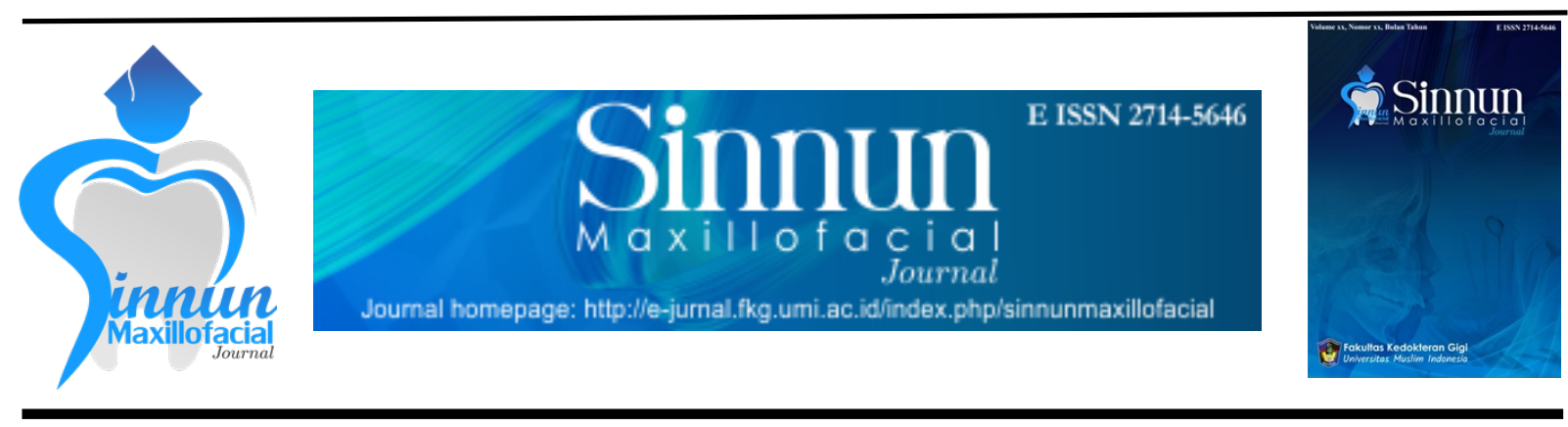

ARTIKEL RISET

URL artikel: http://e-jurnal.fkg.umi.ac.id/index.php/Sinnunmaxillofacial

\title{
Pengaruh Perendaman Susu UHT dan Susu Sapi Segar Terhadap Kekasaran Resin-Modified Glass Ionomer Cement
}

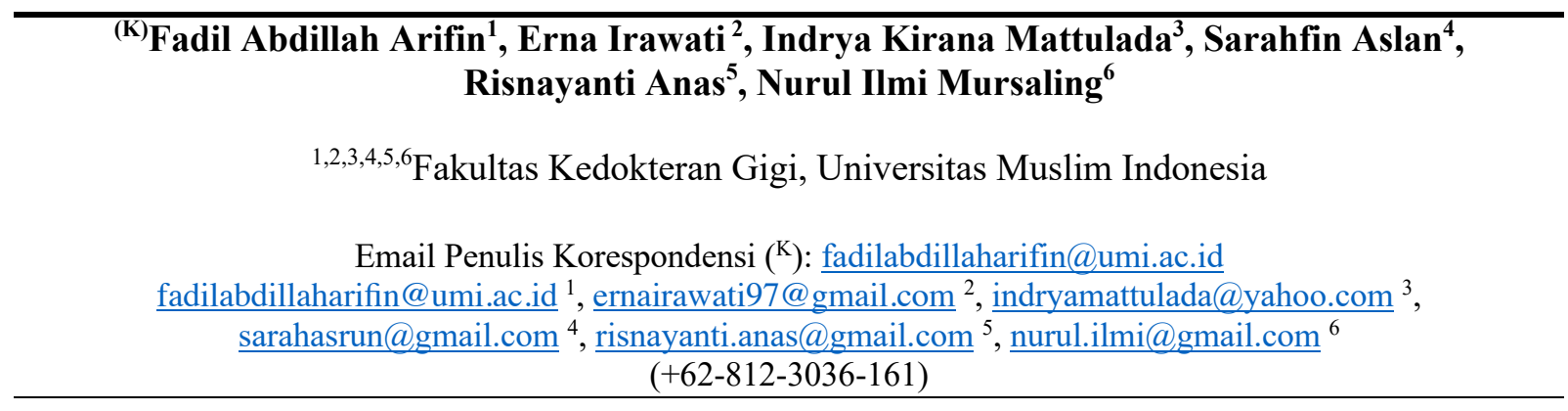

\section{ABSTRAK}

Pendahuluan: Pengembangan resin-modified glass ionomer cement dimulai sejak tahun 1967 untuk memperbaiki sifat fisik dan mengurangi sensitivitas air dari glass ionomer cement konvensional. Resin-Modified Glass Ionomer Cement (RMGIC) sebagai bahan kedokteran gigi memiliki beberapa keuntungan yaitu: RMGIC dapat melepaskan fluoride, kekuatan RMGIC lebih besar dibandingkan dengan glass ionomer cement konvensional, dan estetika lebih baik daripada Glass Ionomer Cement. Tujuan Penelitian: Untuk mengetahui pengaruh perendaman susu UHT dan susu sapi segar terhadap resin-modified glass ionomer cement. Bahan dan Metode: Penelitian ini menggunakan metode Eksperimental laboratorium yaitu pengujian yang dilakukan di laboratorium dengan bentuk penelitian berupa Pre Test-Post Test with Control Group Design. Jenis penelitian yang dilakukan adalah True Eksperimental Laboratorium. Hasil: Berdasarkan uji one way anova sebelum perendaman diperoleh p-value sebesar 0,795 ( $>00,05)$ Berdasarkan uji one way anova setelah perendaman diperoleh $p$-value sebesar 0,669 ( $\mathrm{p}>0,05)$ Berdasarkan uji post hoc multiple comparison diperoleh perbedaan rata-rata antara susu sapi segar dan susu UHT sebesar 0,1114500, untuk aquades dan susu UHT sebesar -0,022000. Kesimpulan: Tidak terdapat perubahan yang signifikan terhadap kekasaran resin-modified glass ionomer cement.

Kata kunci: Kekasaran; RMGIC; Susu UHT

\section{PUBLISHED BY:}

Fakultas Kedokteran Gigi

Universitas Muslim Indonesia

Address:

J1. Padjonga Dg. Ngalle. 27 Pab'batong (Kampus I UMI)

Makassar, Sulawesi Selatan.

Email:

sinnunmaxillofacial.fkgumi@gmail.com,
Article history: (dilengkapi oleh admin)

Received 14 Februari 2021

Received in revised form 14 Februari 2021

Accepted 14 Februari 2021

Available online 27 April 2021

licensed by Creative Commons Attribution-ShareAlike 4.0 International License. 


\section{ABSTRACT}

Introduction: The development of resin-Modified glass ionomer cement began since 1967 to improve the physical properties and reduce the water sensitivity of the conventional cement ionomer glass. Resin-Modified Glass Ionomer Cement (RMGIC) as a dental material has several advantages. RMGIC can release fluoride, the power of RMGIC is greater than with conventional glass Ionomer cement, and the aesthetic is better than glass Ionomer cement. Objectives: To discover the effect of immersion milk and fresh cow's milk on the roughness of ResinModified Glass Ionomer Cement. Materials and Methods: This study used experimental laboratory methods. The tests conducted in laboratories were Pre-Test and Post Test with Control Group Design. Type of research conducted was True Experimental laboratory. Results: Before immersion, P-value was 0.795 ( $p>0.05)$ through one-way ANOVA. After immersion P-value obtained was 0.669 ( $p>0.05$ ). Based on the Post hoc multiple comparisons, it was obtained the average difference between fresh cow's milk and the UHT milk by 0.1114500 (Aquades) and by-0.022000 (UHT milk). Conclusions: the research did not find significant changes in the roughness of the resin-modified glass ionomer cement.

Keywords: Roughness; RMGIC; UHT milk

\section{PENDAHULUAN}

Resin-Modified Glass Ionomer Cement (RMGIC) atau Semen Ionomer Kaca Modifikasi Resin merupakan salah satu bahan restorasi yang digunakan di bidang kedokteran gigi. Pengembangan resinmodified glass ionomer cement dimulai sejak tahun 1967 untuk memperbaiki sifat fisik dan mengurangi sensitivitas air dari glass ionomer cement konvensional. Resin-Modified Glass Ionomer Cement (RMGIC) sebagai bahan kedokteran gigi memiliki beberapa keuntungan yaitu: RMGIC dapat melepaskan fluoride, kekuatan RMGIC lebih besar dibandingkan dengan glass ionomer cement konvensional, dan estetika lebih baik daripada glass ionomer cement. ${ }^{1}$ Kemampuan material dalam menyerap air dan larut dalam air dapat mempengaruhi kelenturan, kekuatan tekan dan kekasaran permukaan bahan restorasi. Kekasaran permukaan bahan restorasi dapat meningkatkan kemungkinan kolonisasi bakteri dan maturasi plak sehingga memperbesar kemungkinan terjadinya karies sekunder dan inflamasi pada jaringan periodontal. Karakteristik permukaan seperti kekasaran bahan tumpat menjadi hal penting. Apabila permukaan restorasi kasar, dapat terjadi timbunan plak gigi dan perubahan warna tumpatan, yang dalam jangka panjang akan merusak gigi dan jaringan pendukungnya. Permukaan gigi dan restorasi dipengaruhi oleh minuman asam dengan $\mathrm{pH}$ asam memutuskan ikatan ionik pada permukaan bahan restorasi gigi. ${ }^{1,2}$

Makanan dan minuman yang manis kuat kaitannya dengan karies gigi anak. Pembentukan dan komposisi dari makanan manis mengambil peran penting karena mengandung glukosa dan sukrosa. Salah satunya adalah susu yang kebanyakan dari anak-anak senang dan sering mengkonsumsinya. Susu adalah bahan pangan yang sangat baik bagi kehidupan manusia terutama pada anak-anak karena komposisinya yang ideal. Selain itu susu juga mengandung semua zat yang dibutuhkan oleh tubuh, semua zat makanan yang terkandung didalam susu dapat dimanfaatkan oleh tubuh. Air susu kaya akan 
protein, lemak dan karbohidrat (terutama laktosa). Komponen karbohidrat yang utama pada susu adalah laktosa, yang difermentasi oleh mikroorganisme, khususnya golongan bakteri asam laktat, untuk pertumbuhannya dan menghasilkan metabolit utama berupa asam laktat yang mengakibatkan susu menjadi asam. Umumnya susu yang dikonsumsi oleh masyarakat diperoleh dari susu sapi dan susu kambing. ${ }^{3,4}$ Susu juga disajikan dalam berbagai bentuk sediaan seperti susu bubuk, susu cair atau UHT (Ultra High Temperature) dan susu kental manis. Masing-masing bentuk sediaan susu memiliki kadar glukosa dan kalsium yang berbeda-beda. ${ }^{3}$

Berdasarkan penelitian Andina (2011), kontak dalam waktu lama antara bahan restorasi glass ionomer cement dengan lingkungan yang bersifat asam $(\mathrm{pH}$ rendah) dapat meningkatkan kekasaran permukaannya. Salah satu minuman yang mempengaruhi $\mathrm{pH}$ saliva ialah susu. Penurunan $\mathrm{pH}$ saliva terjadi setelah mengkonsumsi susu karena kandungan karbohidrat seperti laktosa dalam susu difermentasi oleh bakteri kariogenik dan menghasilkan produk asam yang dapat menurunkan $\mathrm{pH}$ saliva. Nilai pH susu segar normal yaitu berkisar antara 6,3 sampai 6,98 (Standar Nasional Indonesi, 2011). Susu UHT (Ultra High Temperature) merupakan produk susu segar yang disterilkan pada suhu lebih dari $136^{\circ} \mathrm{C}$ selama lebih dari 4 detik. Susu UHT memilih kandungan antioksidan yang tinggi dan juga memiliki kadar karbohidrat yang lebih rendah. Kandungan antioksidan yang tinggi merupakan antikariogenik serta antibakterial yang dapat mengurangi terjadi pemecahan karbohidrat menjadi asam laktat dan asam aspartan oleh bakteri sehingga nilai $\mathrm{pH}$ saliva tetap dalam kondisi stabil. ${ }^{2,5,6,7}$

Berdasarkan hasil penelitian Dewi (2019) mengenai kekasaran permukaan resin-modified glass ionomer cement setelah direndam didalam minuman susu sapi segar yang sudah steril ditemukan adanya perbedaan perubahan kekasaran permukaan resin-modified glass ionomer cement yang signifikan setelah dilakukan peerendaman di dalam minuman susu sapi segar yang sudah steril dengan waktu yang berbeda yaitu 2, 4 dan 6 jam. ${ }^{8}$ Berdasarkan literature tersebut peneliti tertarik melakukan penelitian tentang pengaruh perendaman susu UHT dan susu sapi segar terhadap kekasaran permukaan resinmodified glass ionomer cement.

\section{METODE}

Penelitian ini menggunakan metode True Eksperimental Laboratorium dengan rancangan pre test-post test with control group design. Jenis penilitian adalah true eksperimental laboratorium yang dilakukan di Laboratorium Mikrobiologi Fakultas Farmasi UMI dan Balai Latihan Kerja (BLK) Makassar. Sampel dalam penelitian ini adalah resin-modified glass ionomer cement yang dibuat dalam bentuk cakram bulat dengan diameter $5 \mathrm{~mm}$ dan ketebalan $2 \mathrm{~mm}$. Subjek penelitian ini adalah kelompok perlakuan susu UHT, susu sapi segar sebagai kelompok kontrol positif serta aquades steril sebagai kelompok kontrol negatif. Data penelitian kemudian dianalisis menggunakan uji One Way Anova. 


\section{HASIL}

Penelitian mengenai pengaruh susu UHT dan susu sapi segar terhadap kekasaran permukaan resin-modified glass ionomer cement. Penelitian ini dilakukan mulai bulan November sampai Desember tahun 2019. Adapun subjek penelitian ini terdiri dari susu UHT, susu sapi segar, dan aquades steril sebagai kelompok kontrol yang memenuhi kriteria seleksi sampel yang telah ditentukan sebelumnya. Sebelum dilakukan perendaman pada sampel dilakukan uji $\mathrm{pH}$ terrhadap subjek penelitian. Hasil pengukukuran $\mathrm{pH}$ pada susu UHT, susu sapi segar dan aquades sebegai berikut.

Tabel 1. Hasil pengukuran uji pH pada susu UHT, susu sapi segar, dan aquades

\begin{tabular}{cc}
\hline Larutan & pH \\
\hline Susu UHT & 6,7 \\
\hline Susu Segar & 6,4 \\
\hline Aquadest & 7,0 \\
\hline
\end{tabular}

Jumlah sampel dalam hal ini resin-modified glass ionomer cement yang digunakan pada penelitian ini yaitu sebanyak 18 sampel dan subjek yang dibagi ke dalam 3 kelompok yaitu kelompok yang dilakukan perendaman dalam susu UHT, susu sapi segar, dan aquades (kelompok kontrol) masingmasing sebanyak 6 sampel.

Penelitian ini dilakukan dengan dua kali pengambilan data yaitu sebelum dan setelah perendaman (pre \& post test design and control group design). Setiap kelompok subjek dilakukan perendaman masing-masing selama 36 jam 30 menit, dan dilakukan pengukuran kekasaran permukaan menggunakan alat Mitutoyo Surftest SJ-310 sebelum dan setelah dilakukan perendaman dalam larutan uji di Balai Latihan Kerja (BLK) Makassar. Data yang diperoleh diolah dan dianalisis menggunakan program SPSS 23 dengan uji one way anova. Hasil penelitian ditampilkan dalam tabel sebagai berikut. 
Tabel 2. Nilai rata-rata kekasaran resin modified glass ionomer cement sebelum dan setelah perendaman

\begin{tabular}{|c|c|c|c|}
\hline Perlakuan & Kelompok & Mean \pm SD & $\begin{array}{c}\text { P-Value } \\
\text { (Sig.) }\end{array}$ \\
\hline \multirow{3}{*}{$\begin{array}{c}\text { Sebelum } \\
\text { perendaman }\end{array}$} & Susu UHT & $0.32117 \pm 0.122998$ & \multirow{3}{*}{0,795} \\
\hline & Susu sapi segar & $0.37867 \pm 0.206429$ & \\
\hline & Aquades & $0.40100 \pm 0.270675$ & \\
\hline \multirow{4}{*}{ Setelah perendaman } & Cum InUT & $0.41667 \pm$ & \multirow{4}{*}{0,669} \\
\hline & susu UH & 0.276443 & \\
\hline & Susu sapi segar & $\begin{array}{c}0 . .53117 \pm \\
0.355180\end{array}$ & \\
\hline & aquades & $\begin{array}{c}0 . .39467 \quad \pm \\
0.167969\end{array}$ & \\
\hline
\end{tabular}

Berdasarkan tabel 2 diperoleh hasil uji one way anova untuk melihat perbedaan tingkat kekasaran pada sampel yang belum dilakukan perendaman. Berdasarkan uji one way anova diperoleh $p$-value sebesar $0,795(\mathrm{p}>0,05)$ atau lebih besar dari 0,05. Artinya bahwa tidak terdapat perbedaan tingkat kekasaran pada sampel yang belum dilakukan perendaman.

Berdasarkan tabel 2 diperoleh hasil uji one way anova untuk melihat perbedaan tingkat kekasaran pada sampel yang telah dilakukan perendaman. Berdasarkan uji one way anova diperoleh $p$-value sebesar 0,669 $(\mathrm{p}>0,05)$ atau lebih besar dari 0,05. Artinya bahwa tidak terdapat perbedaan tingkat kekasaran pada sampel yang telah dilakukan perendaman.

Tabel 3. Perbandingan kekasaran resin-modified glass ionomer cement sebelum perendaman

\begin{tabular}{cccc}
\hline Kelompok & $\begin{array}{c}\text { Perbedaan rata-rata } \\
(\text { Mean Differenc) }(\boldsymbol{\mu m})\end{array}$ & $\begin{array}{c}\text { P-value } \\
\text { (Sig.) }\end{array}$ & $\begin{array}{c}\text { P-value } \\
\text { (Sig.) }\end{array}$ \\
\hline $\begin{array}{c}\text { Susu sapi segar }- \\
\text { UHT }\end{array}$ & 0,057500 & 0,883 & 0,789
\end{tabular}




\begin{tabular}{ccc}
\hline Aquades - UHT & 0,079833 & 0,789 \\
\hline Aquades - susu sapi & 0,022333 & 0,981 \\
segar & & \\
\hline
\end{tabular}

Berdasarkan tabel 3 diperoleh perbedaan antara susu sapi segar dengan UHT sebelum perendaman sebesar $0.057500 \mu \mathrm{m}$ dengan signifikansi perbedaan sebesar 0,883 . Artinya bahwa tidak terdapat perbedaan yang signifikan antara susu sapi segar dengan UHT sebelum perendaman. Selanjutnya diperoleh perbedaan nilai rata-rata dari aquades dengan UHT sebelum perendaman. Hasil penelitian menunjukkan bahwa perbedaan rata-rata yang diperoleh yaitu sebesar $0,079833 \mu \mathrm{m}$ dengan nilai signifikansi perbedaan yaitu 0,789 atau $p$-value lebih besar dari 0,05 . Hal ini menunjukkan bahwa tidak terdapat perbedaan yang signifikan antara susu sapi segar dengan UHT sebelum perendaman. Selanjutnya, diperoleh nilai rata-rata dari aquades dengan susu sapi segar sebelum perendaman. Hasil penelitian menunjukkan bahwa diperoleh perbedaan rata-rata yaitu sebesar $0,022333 \mu \mathrm{m}$. Dengan nilai signifikansi sebesar 0,981 atau $p$-value lebih besar dari 0,05. Hal ini menunjukkan bahwa tidak terdapat perbedaan yang signifikan antara susu sapi segar dengan UHT sebelum perendaman.

Tabel 4. Perbandingan kekasaran resin-modified glass ionomer cement setelah perendaman

\begin{tabular}{cccc}
\hline Kelompok & $\begin{array}{c}\text { Perbedaan rata-rata } \\
(\text { Mean Differenc }) \\
(\boldsymbol{\mu m})\end{array}$ & $\begin{array}{c}\text { P-value } \\
(\text { Sig. })\end{array}$ & $\begin{array}{c}\text { P-value } \\
\text { (Sig.) }\end{array}$ \\
\hline $\begin{array}{c}\text { Susu sapi segar - } \\
\text { UHT }\end{array}$ & 0,114500 & 0,759 & \\
\hline Aquades - UHT & $-0,022000$ & 0,677 & \\
\hline Aquades - susu sapi & & & \\
segar & $-0,136500$ & 0,677 & \\
\hline
\end{tabular}

Berdasarkan tabel 4 diperoleh perbedaan antara susu sapi segar dengan UHT sebelum perendaman sebesar $0,114500 \mu \mathrm{m}$ dengan signifikansi perbedaan sebesar 0,759 . Artinya bahwa tidak terdapat perbedaan yang signifikan antara susu sapi segar dengan UHT setelah perendaman. Selanjutnya diperoleh perbedaan nilai rata-rata dari aquades dengan UHT sebelum perendaman. Hasil penelitian menunjukkan bahwa perbedaan rata-rata yang diperoleh yaitu sebesar $-0,022000 \mu \mathrm{m}$ dengan nilai signifikansi perbedaan yaitu 0,990 atau $p$-value lebih besar dari 0,05 . Hal ini menunjukkan bahwa tidak 
terdapat perbedaan yang signifikan antara susu sapi segar dengan UHT setelah perendaman. Selanjutnya, diperoleh nilai rata-rata dari aquades dengan susu sapi segar sebelum perendaman. Hasil penelitian menunjukkan bahwa diperoleh perbedaan rata-rata yaitu sebesar $-0,136500 \mu \mathrm{m}$. Dengan nilai signifikansi sebesar 0,677 atau $p$-value lebih besar dari 0,05. Hal ini menunjukkan bahwa tidak terdapat perbedaan yang signifikan antara susu sapi segar dengan UHT setelah perendaman.

\section{DAFTAR PUSTAKA}

1. Kurniawati, A. C., Pengaruh Perendaman Infused Water dan Penyikatan Gigi Terhadap Kekasaran Permukaan Semen Ionomer Kaca Modifikasi Resin, Jurnal Material Kedokteran Gigi, 2014, 3 (2): 68-70

2. Permatasari, A. P., Nahzi, M. Y. I., Widodo, Kekasaran Permukaan Resin-Modified Glass Ionomer Cement Setelah Perendaman Dalam Air Sungai, Dentino (Jurnal Kedokteran Gigi), 2016, 1(2): 165-166

3. Putri, A. D., Rahmawati, A. D., Perbedaan Kekerasan Email Gigi Desidui Antara Sebelum dan Sesudah Perendaman dengan Beberapa Jenis Sedian Susu, Jurnal Material Kedokteran Gigi:2930

4. Sujaya, I. N., dkk, Identifikasi dan Karakteristik Bakteri Asam Laktat Isolat Susu Segar Sapi Bali, Jurnal Veteriner, 2016, 7 (2): 156

5. Seralurin, I. T., dkk, Perbedaan pH Saliva Setelah Mengonsumsi Susu Sapi Murni dan Susu Sapi Bubuk, Jurnal e-Gigi, 2018, 6(1): 2-4

6. Riyanto, J, dkk, Produksi dan Kualitas Susu Sapi Perah Penderita Masitis yang Mendapat Pengobatan Antibiotik, Sains Peternakan, 2016, 14 (2): 34

7. Savira, C. N., dkk, Perbedaan pH Saliva Sebelum dan Sesudah Mengkonsumsi Susu Formula dengan Susu UHT (Studi pada Anak di Panti Asuhan Nirmala Banda Aceh), Journal Caninus Dentistry, 2017, 2 (4): 151

8. Dewi, Y. R., 2019, Kekasaran Permukaan Semen Ionomer Kaca Modifikasi Resin Setelah Direndam Didalam Minuman Susu Sapi Segar Yang Sudah Steril, Skripsi Sarjana USU: 29

9. Bollen, C. M. L., dkk, 1997, Comparison of Sorface Roughness of Oral Hard Materials to The Threshold Surface Roughness for Bacterial Plaque Retention : A Review of The Literature, Dent Mater, 260-261

10. Agustina, Y., dkk, Pengaruh Variasi Waktu Fermentasi Terhadap Kadar Laktosa, Lemak, pH dan Keasaman Pada Susu Sapi Yang difermentasikan menjadi Yogurt, Jurnal Kimia Mulawarman, 2015, 12 (2): 97-98

11. Fuzukawa, M., dkk, 1990, Mechanism for Erosion of Glass-Ionomer Cements in an Acidic Buffer Solution, Journal of Dental Research 66 (12):1772

12. Bajwa, N. K., Pathak, A., 2014, Change In Surface Roughness Of Esthetic Restorative Materials After Exposure To Different Immersion Regimes In A Cola Drink, Hindawi Publishing Corporation: 4 